JOURNAL OF THE JAPANESE ASSOCIATION OF PETROLEUM TECHNOI.OGISTS

VOL. 18, NO. 1 (Jant., 1953)

\title{
泥水比抵抗を通常の電気検篔と同時に測定する方法*
}

\author{
淵田隆門** \\ (昭和27牛10月14日受理)
}

\section{Simultaneous Recording of Mud Resistivity Log and Usual Electrical Logs \\ By}

Takato Fuchina

\begin{abstract}
The estimated value of the subsurface mud resistivity, which is calculated from the surface sample mud data with the correction to the temperature only, seems to the writer to involve some uncertainties. Because, the chemical composition of the mud in place may be not necessarily same as that of the mud sample.

And therefore, the writer has developed the new device which can record simultaneously SP, short normal resistivity $(30 \mathrm{~cm})$, long normal resistivity $(90 \mathrm{~cm})$ and mud resistivity with the quadruple cord, and tested it practically.

Some of the mud resistivity curves obtained experimentally are shown in Fig. 6. They show that the mud resistivity variation with depth is more complicated than expected solely with respect to the temperature.
\end{abstract}

\section{1. 緒言}

電気檢買において，坑牛を充している泥水の比抵抗が 地曾の見脚比呧抗やSP の湘定值に影響するるのである ことは，既こよく知られていると扣りであるっ従来の電 気杜状図に乱いて，それぞれの場合の泥水の比抵抗を示 してあるの活，上記の事瑇への参考たらしめよ5として

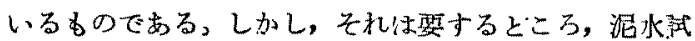

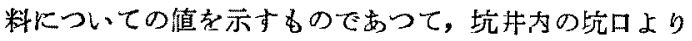
坑底末でに分布存在している泥水の，その位䈯における 值を示するのではい。そして，たとえぱ，ある染度に おける比抵抗推定するには，泥水の組成が同一の6の

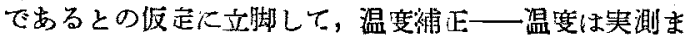
たは推定による—をすることになつている。

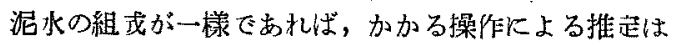

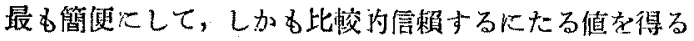
ことができるしかし，泥水の組成は，はたして常にい

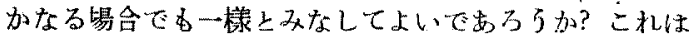
筆者が古くから抱いていた㩆念であつて，この折究をす るに至つた理由はそろいうとこるに根ざしている。

筆者は今まてに，天然ガスまたは含沃度塩水採取省目

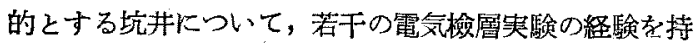

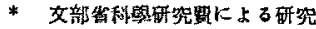

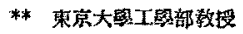

つているが，経験を積さにしたがつてますます上述の疑

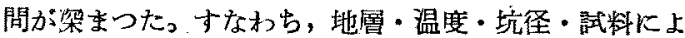
る泥水比抵抗などに大差はないと思われるにるかかわら ず，見掛比抵抗拄の值，特に $\mathrm{R}_{1}$ と $\mathrm{R}_{\mathbf{2}}$ の相互関俰— $\mathrm{R}_{1} ， \mathrm{R}_{2}$ はそれぞれ $30 \mathrm{~cm} ， 90 \mathrm{~cm}$ の2極方式見掛比抵

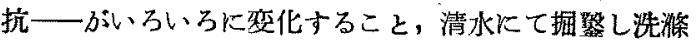

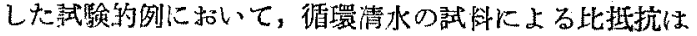
大きいにるか加わらず，测定中の拀井内水は㙏水でるつ て，比抵抗が小ざいのではないかと思われるよ5な見脚 比抵抗を得たりするなど, 試料による泥水比抵抗值をす つて，坑井内の泥水のそ机を推盯することの不安を增大 せしめる瓷针が増加したのでかる，この牙究はここれら 最近の经験を直接の動幾としておこなうに至つたすので ま。

坑井内の泥水の比抵抗を，良来执こなわれてきた通常

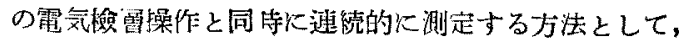
ここに報告する方式は䍃者の若婪になるるのてあつて， 比較的簡便なるにかからず允分に春用方式として成立

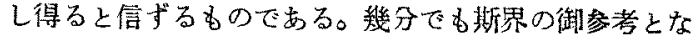
れじ幸でるる。

\section{2. 坑井內泥水比抵抗の連続測定について}

一般に電解液の電気比抵抗の直接測定は，適当なる䨪 気比担抗測定容器 (Resistivity Cell) によつてなるれ 
る。泥水の電気比抵抗る，それが電解液たる性質老持つ ことの1つの表現であるから，上と同じ原理とよつて澌

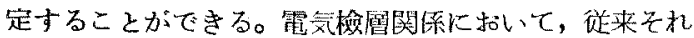
が沼水池一の特製の投込式签器によつたにせよ，あるい

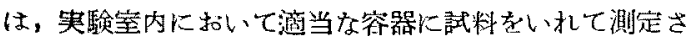
れたにせよ，いずれる根本原理的には同じわけでする。

そこで，坑井内の泥水此抵抗の連続測定のためには， 適当な客器を坑井内に㨉入し弓るようにし，加そ机の 移動儿件、容器中の泥水が流動して入北替る如く, くふ らすればよいことは容易代考充ら扎るこころである。た とえば，篗者が投込式突器として徉来使用してきたのは，

第 1 図第 1 园の如き 4 極式容器であるが，こ机な

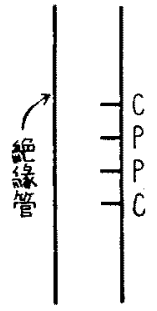
どはそのまま直ちにその目的に使うことが できる。しかし，こ北は測定電界をなるべ く容器内部に局限し，かつ，電極の活れな ぞによる接触抵抗の影響が，なるべくきか ない上ろにするため一そその他飞導線の抵 抗がきいてこないという利点がある一 4 極式にしてあるのでるし，かかる形式の 容器によるとすれば、どうしてもそのため に4芯の導線を必要と寸る。ただ，泥水比抵抗だけを單 独に測定するのであ杖，かかる形式によるのが最も理 想的であるが(もちろん，4芯導線があるものとして： しかし，通常の電気檢層操作々同侍に泥水比抵抗をる測 定しようといろことになると，そのために4芯を增設す ることは，実際問題としてけつして簡單容易なことから ではない。

そこで，次に芯数を減らすために容易 に考えられるのは，第2図の如き2極式容 器である。2 極式は実験室において一般 実験用によく使われるのであるが，長い 導線の場合はその抵抗が測定值にきいて くること，電極面の污狄などが 4 極式よ りききやすいことなどにより，4極式ほ どには理想的でないが，2芯だけ節約て きるのは実用的には大きな利点である，

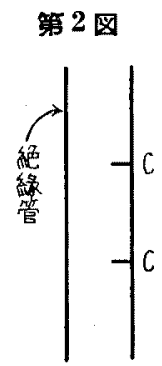
しかし，それですな打2芯だけの兽設は免がれない。 あつと芯数䘮減らそらとすれば，けつきよく最少の1 芯といらことになるが，筷者は第 3 图の如き容器老くふ らすることによつて，それが可能であることを確めた。 それいは，測定原理的には 2 極式容器と同じであるが，2 極式火要する 2 芯の導線のうち 1 芯を大地に轉䠔したわ けである。次節に狲てて，すつと具体的に述へ上う。

\section{1 芯導線による泥水比抵抗の連続測定 法の原理}

第 3 図は，1芯線によつて泥水の比抵抗老測定するた 第 3 図 めの電極として，新しく考案したるのの 拿 證明図 (断面)である。要点を列肜すれ ば次の如くである。

(1) 長い絶緣管(ベークライト) の中 央と两端に，十字形にステンレス線一

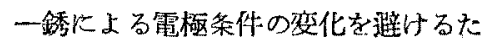
め，白金の如きはさらに良好である万 一の雷極 $\mathrm{C}_{1}, \mathrm{C}_{\mathrm{n}}, \mathrm{C}_{3}$ ，を張つてある， 泥水はこの管の中をよく流㗢寸る。 （2）絕緣管の外侧には金属管（鉄管に

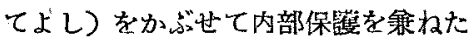
接地電極とし，それは $\mathrm{C}_{2} \mathrm{C}_{3}$ K接続 されている。

（3）Ｇは縃線線とよつて測定用導線 (1芯導線)に接続される。絕線線はべ 一クライト管の内部を通寸上きは管壁に固定し，容器 常数が变らない上う留意寸る。

(4) 電流は導線 $\rightarrow \mathrm{C}_{1}$ \泥水 $\rightarrow \mathrm{C}_{2}>\rightarrow$ 鉄管 $\rightarrow$ 大地 に、あるいはこの逆向に流れる，

(5) $\mathrm{C}_{1}-\mathrm{C}_{2}, \mathrm{C}_{1}-\mathrm{C}_{3}$ ，はそれぞれが 2 極式容器をなし ている。したがつてこの場合は 2 極式が並列に接続 されていることになる。

次に測定回路の響明図を第 4 図に示寸。電流は㨁流在 第 4 図

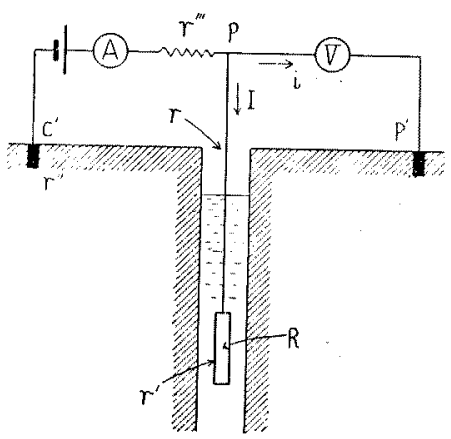

コミュテーターによつて轉換するのであるが，それは 源理の說明上必要もないし，また技術的にも周知のこと であるので省略してある。 $\gamma$ は導線の抵抗， $\mathrm{R} は \mathrm{C}_{1}$ 鉄管間の抵抗， $\gamma^{\prime}$ は鉄管の接地抵抗， $\gamma^{\prime \prime}$ は坑井上りな るへくく遠距滩に設置せられた地上の電流電極 $\mathrm{C}^{\prime}$ の接地 抵抗， $\gamma^{\prime \prime \prime}$ は電流調整者兼ねた電流安定用担抗， $\mathrm{P}^{\prime}$ は

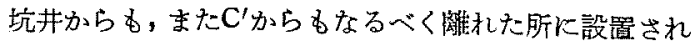
た地上の電位電極，Vは们部抵抗の大きい耪錄用ガルバ 


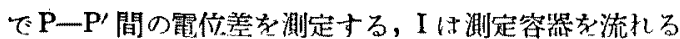

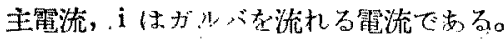

陚評上の注意としては次の如きものがある。

(1) $\mathrm{R} \gg \mathrm{r}^{\prime}$ となるようにする。

（2）なるべく R》r Kなるようにする。しかし鬴正 をするつもりならば, 必ずしも艺万でなくてあよい。

(3) $\mathrm{r}^{\prime \prime \prime} \gg \mathrm{R}$ になるよ弓にする。 $\mathrm{R}$ は泥水の比抵沆に 応じて变化するが，それによつては電流がなるべく变 化しないようにするためでるる。

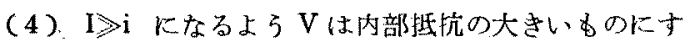
る。Vを霓生計としての理想に近ずけるため。

この湖定回路の等洒回路を走せば第 5 园の如くです
第 5 図

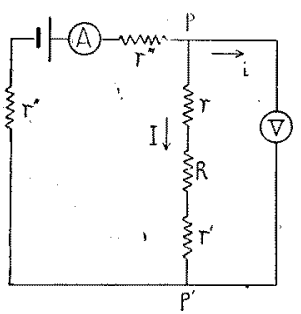

る。この図では，Vの内部拄 抗が大きくて $\mathrm{P}^{\prime}$ の接地拱抗 の影縓は無視できるのでそれ は筧略してある。

さて，上钎の如き設計上の 注意が払われたとすれいば， $\mathbf{P}$

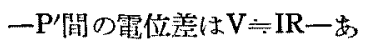
るいは, $V \fallingdotseq I(R+r)=I R+$ Ir た Ir は一定の既知量— となるのて，I をある值に一定にしてVを制測寸れば R を知ることができる。しからばあらかじめ較正された 容器常数 KKよつて

$$
\rho=\mathrm{KR}
$$

によつて，泥水比抵抗 $\rho$ を知ることがでる。

\section{4.，実験}

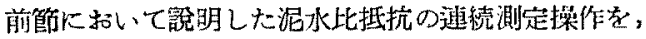

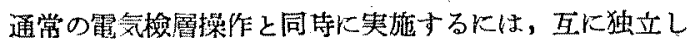
た電界老作り出すようにすることが，特火後者の側より の必要条件となる。このためには，筆者孫同一の直流電

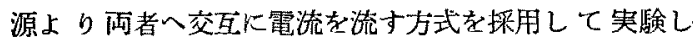
た。コミュテーターの設計に切篔ごとKおこる過渡現象

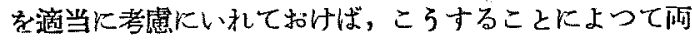
測定操作は互に独立のるのとみなしてよいのである。か くすることによつて, 解者が徉来採用してきた程度の通

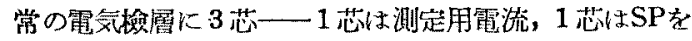

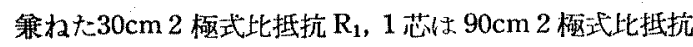
$\mathrm{R}_{2}$ — , 泥水比抵抗測定に1芯，合㭏 4 芯の導䠌があ れば，同者の同時則定党実行に移すことができる。

比抵抗測定容器としては，泥水の流動が滑加に扣こな われるためには太くて短い方がよいこととなるが，一方 直径に比べて長さの長い、ぼR対 $\rho$ の直線性が，広籍目 の $\rho$ K対して成立する傾问がある一一長い任ど, 電極附 近の複雜な電界に括ける抵抗に比べて，泥水杜の抵抗は

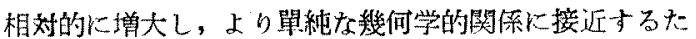

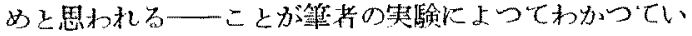
るので, 余り短い形のあのは好ましくない。これは $\mathbf{r}^{\prime}$ を满才ための采件とる合致していることである。筆 者は，泥水の他塩水をむ測定する必姴があつたので，

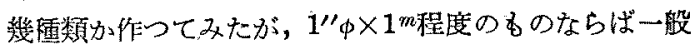
泥水用として，克分実用になるよ弓思执る。すなお ち，1例在むげると，K=0.00328m なる容器ては，泥水 比抵抗 $\rho=3.28 \Omega \mathrm{m}$ のとき $\mathrm{R}=1000 \Omega$ となる計算になる

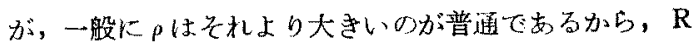

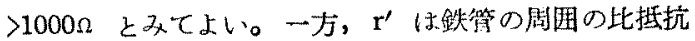

第 6 図

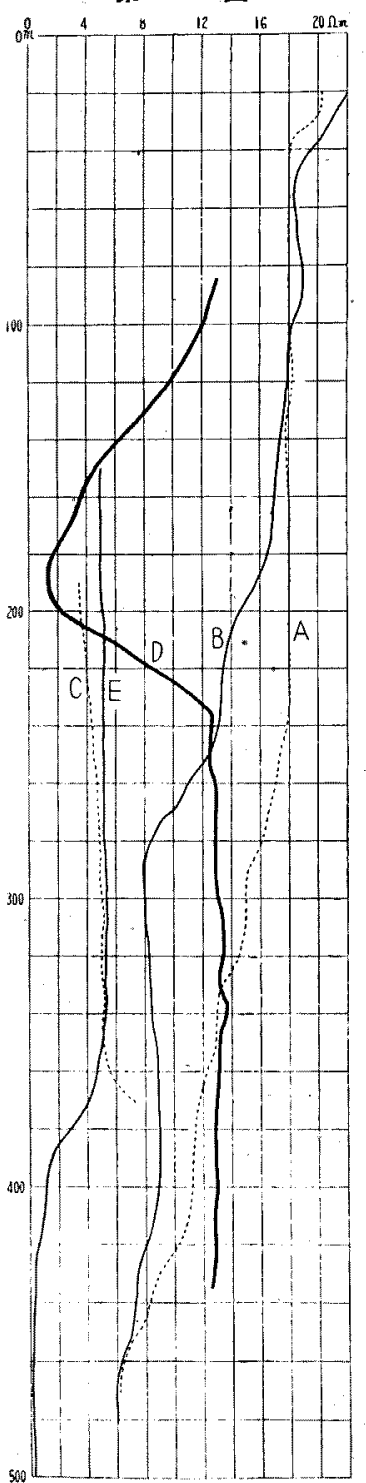
$\rho^{\prime}$ 一直ぐ外側は泥水， それより外倒は地筩です る。一比例するのて， 比例常数孝 $\mathbf{r}^{\prime}=c \rho^{\prime}$ な る $\mathrm{c}$ とし水槽実験に招い て大体の見当孛つけてみ たところ，cะ1 $2 \mathrm{~m}^{-1}$ の程度厄ありて、かりに $\rho^{\prime}=10 \Omega \mathrm{m}$ とすれば $\mathrm{r}^{\prime}=$ $10 \sim 20 \Omega$ 程度となり， 夹用的には䌽保 $\mathrm{R} 》 \mathrm{r}^{\prime}$ 在 满している。また，実際 の坑井に颃いて普通には 最る $\rho^{\prime}$ の大くなる浅所 K招いて, $c_{1}$ 極之鉄管者 短絡して訶験したとき— 一それは第 5 図に和いて $\mathrm{R}=\mathrm{o}$ に相当する。一の ガルバのフレがはとんど ないことよりみてる，実 用的には一沁 $R 》 r^{\prime}$ E $R$ $+\mathbf{r} \div \mathrm{R}$ とみなしてよい ことがわかるのである。 なおこの試験のときは導 線は短いのを使用したた め $\mathrm{r} \div \mathbf{0}$ でつた。

さて以上の如き集備と 予想の下に，篗者が今ま てに颃こなつてきた笑験 例から泥水比拱抗だけを 示せば，第6図の如く厄 女る。これには*5例宗 してむり，I=1mAD.C., 


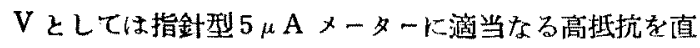

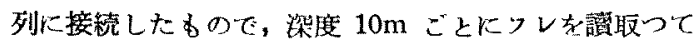
観测したすのである。るとよりVとしては，反照がルバ によつて自動記錄式にした方がよいのであるが，筆者の 実験裝置では備付のつのガルバを通常の電気㮝㬝用使 つてしまうので，とりあえず以上の要領によつたのであ る。泥水比抵抗の变化は絞曼であるので，これでも充分 正しい觀測結:果が得られる。

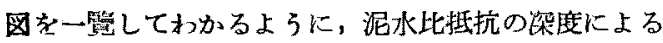
变化は，温度受化に件万整化だけでないことは，極めて 明白である。これららは泥壁の形成が不完全なために，地 層水（塩水）が坑井内に浸入しているとみるのが最 妥 当である5 と思水机るが，具体的仾究は今後の資科の集 皘にまたなければならない。本報告としては，とにかく 上述の如く变化の真相を知る方法が確立されたことを述 べるにとどめたい。ただ，はつきりかかつているとみて よいと思机ることだけは，参考のため附言しておく。

まゔ，Cの下端に括いて なつてResistivity Factor が增大したためと思わ机る。 これは繰返し觀測してみたが同じことがみられたっ他て す若千その傾向がみられるのがあつた。

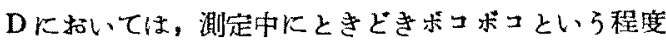
のガスの自磺がみられたことと，比抵杭 $\mathrm{R}_{1}$ 曲線ならび に,このD伷腺の形とより判䉼すれば，恐らく 190〜200m

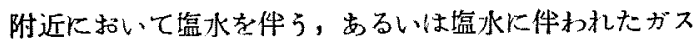
の浸入があり，勀きよく浸入塩水はガスリソト作用に 上り漸次上方へ擴散し，165m に下端を有するケーシン グの中までも及んだすのと思和机る。200〜230mの間は

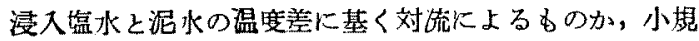
模の浸入が分散しているすのがは直ち代判定ができな い。

Eは久しく䃍行中(157m井以下裸坑)であつたが塩水濃 度低下のため中止し，改めて泥水在循環洗涤し初めて電 気检兽を試みたるのである。この沉井はこれより以前 下，揚水中止淔後の静止した坑井内水の比抵抗の速统測 定（このときは第 1 図の如き 4 極式）試みたことのあ るるので㟧つて，そのときの判断では $390 \mathrm{~m}$ 附近に，恐 らく断算よりの低濃度水の浸入が招こつたらしいといら ことになつていたものてあり，また混水循環中も逻水が
みられたるのである。このようK異常のある坑井である 吕，泥水の比担抗变化は图の如くて，390m 上り下方は 萻しく塩水の浸入がみられ，450m 附近より以下は，0.2 $\Omega \mathrm{m}$ 程度をで低下して, 利用し得る含沃庭壏水となつて しまつていることを示している。かかる条件下に猢る 電気檢層の結紧は，SP曲線の基線のズレ，比抵抗曲線 の平滑化の傾向が当然みられるのであつて(揭载省略), このE井線と照合してみるとき，上く事情が察せられて 意老强らするものがある。

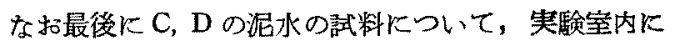
て測定した比抵抗の值は，それぞれ，4.13 $\Omega \mathrm{m}\left(26.0^{\circ} \mathrm{C}\right)$, $11.5 \Omega \mathrm{m}\left(26.1^{\circ} \mathrm{C}\right)$ で数つたことを附加えて括く。

\section{5. 結言}

この報告は，坑井内の泥水の比抵抗を深さに沿つて連 続的に，しか子彷来の通常の電気檢層と同時に測定する1. つの方法として，筆者が考案した方法の原理を說明し， からそれを実験的に試験し可能なることを示している。

そして泥水比担抗の庭化は事情によつていろいるの場 合があるらしいのた, 従来の如く泥水試料についての測 定值に單なる温度補正を施しただけの推定では，事実の 把握が相嵟な場合があろると指摘した。

筆者は，かかる新しい方法の実施が，事情の許寸限り に做いて望ましいるのと考文るし，それが実施されて資 料が集樍されれれば，將来に牯いて電気杜状図の解釈，特 下定量的解析下必ず中寄与するところ大でむろろと信ず るものである。

この研究の実地款験に当つては, 相生工業(株)の千集 県下の坑井を試験井として提供して頂いた。同社の末国 社長・近藤專務の研究への御理解と御嗳助と, また央駼 に際しての関係社員各位の御壮話に对し，ここに厚く招 禮申上げるものである。

東大助手島津孝・石原義雄の两君は筆者の実験助手々 して常に熱心に研究を援けられた。また神津敬子孃には 研究に伴う計算・慗図などにおいて非常にお姏話になつ たっこれらら諾君に心より感謝する。

最後に，この所究は昭和26年度，同27年度文部省科学 研究费に毁弓ところが多いこと老申添え，謝意を表して 扰く。 